DOI

\title{
ІНТЕНСИВНІСТЬ ПРОЦЕСІВ ЛІПІДНОЇ ПЕРОКСИДАЦІї У КРОЛІВ З ХІМІЧНИМ ОПІКОМ РОГІВКИ НА ТЛІ МЕРКАЗОЛІЛ-ІНДУКОВАНОГО ГІПОТИРЕОЗУ
}

\section{○3. Л. Савчук \\ ДВНЗ «Тернопільський державний медичний університет імені І.Я. Горбачевського МОз України»}

РЕЗЮМЕ. У статті проаналізовано результати дослідження інтенсивності процесів ліпідної пероксидації у крові і внутрішньоочній рідині передньої камери ока кролів з хімічним опіком рогівки, викликаним накладанням фільтрувального паперу, змоченого $1 \mathrm{~N} \mathrm{NaOH}$ на тлі попередньо змодельованого мерказоліл-індукованого гіпотиреозу. Встановлено, що у тварин з хімічним опіком рогівки на тлі гіпотиреозу, порівняно з евтироїдними тваринами, виявляється суттєве зниження продукування активних форм кисню мононуклеарними лейкоцитами крові, пригнічення інтенсивності ліпідної пероксидації, що виражається у зменшенні концентрації гідропероксидів ліпідів, ТБК-реагуючих продуктів та основ Шиффа у крові і внутрішньоочній рідині передньої камери ока. Зроблено висновок, що за умов супутнього дефіциту гормонів щитоподібної залози має місце пригнічення активності вільнорадикальних процесів як у місці ураження, так і в організмі в цілому.

КЛЮчОВІ СЛОВА: опік рогівки, гіпотиреоз, ліпідна пероксидація.

Вступ. Опіки очей $\epsilon$ тяжким пошкодженням органа зору, а проблема їх лікування залишається до теперішнього часу гострою і актуальною. Частота опіків очей, за даними різних авторів, складає від 6,1 до 38,4 \% від усіх видів травм органа зору $[6,7,10,11,14,17]$.

Опіки очей найчастіше бувають хімічними 60-85 \%, далі слідують термічні і променеві. 3 хімічних опіків превалюють опіки лугами. За даними R. Kuckelcorn et al. [13] у структурі опіків очей переважали хімічні (89,2 \%), а серед них лужні склали 79,8 \% [19].

Численні дослідження механізмів розвитку опікової хвороби, проведені на гістоморфологічному, біохімічному, імунологічному, електронномікроскопічному рівнях, як в тканинах ока, так і в організмі в цілому, сформували уявлення про патогенез опіків очей, як про багатофакторний, багатокомпонентний і взаємозв'язаний процес, який не обмежується тільки ділянкою ока, а викликає різноманітні патологічні зміни в різних системах організму людини: наростають явища автоінтоксикації і автосенсибілізації, виникають порушення реактивності організму, в процес втягуються імунокомпетентні органи, порушуються ферментні та обмінні процеси, нервоворефлекторні зв'язки, а також виникають зміни крові і кровоносних судин $[1,2,15,19]$.

Перебіг опікової травми залежить від численних факторів, які впливають на реактивність організму. Серед цих факторів значна роль відводиться стану ендокринної регуляції організму. В структурі ендокринної патології одне із провідних місць посідають захворювання щитоподібної залози, а саме гіпотиреоз [16].

Матеріал і методи дослідження. Досліди проведені на статевозрілих кролях породи «Бі- лий велетень» масою тіла 2,5-3 кг, у відповідності з Женевською конвенцією «International Guiding principles for Biochemical research involving animals" (Geneva, 1990) та згідно із Загальними принципами експериментів на тваринах, схваленими на Національному конгресі з біоетики (Київ, Україна, 2001) [4]. В процесі роботи використано 60 кролів.

Гіпотиреоз моделювали згідно з рекомендаціями $[3,12]$. Кролям внутрішньошлунково через металевий зонд вводили мерказоліл (Здоров'я, Україна) у дозі 10 мг/кг у 2 \%-му розчині крохмалю протягом 60-ти днів. Тварини знаходились в умовах, аналогічних для усіх експериментальних груп, та отримували той же самий харчовий раціон. Масу кролів контролювали щотижня, корекцію доз мерказолілу проводили відповідно до зміни маси тіла. Повноту досягнення гіпотиреозу контролювали вимірюванням концентрації трийодтироніну і тироксину в сироватці крові.

Опікову травму викликали шляхом аплікації на рогівку експериментальних тварин фільтрувального паперу діаметром 5 мм, змоченого у $1 \mathrm{~N}$ розчині натрій гідроксиду $(\mathrm{NaOH})$ протягом 30 секунд. Маніпуляції проводили під місцевою епібульбарною анестезією 0,5 \% розчином алкаїну та ретробульбарною анестезією 2 \% розчином лідокаїну.

Досліджували цільну кров, сироватку крові й внутрішньоочну рідину передньої камери ока. Водянисту вологу (humor aquosus) передньої камери отримували за асептичних умов шляхом проколу лімбальної частини рогівки стерильною туберкуліновою голкою, приєднаною до інсулінового шприца у кількості 0,25-0,3 мл з одного ока [18].

Всі піддослідні кролі були поділені на 4 групи: 1 - контрольна група (інтактні тварини); 2 - тва- 
Огляди літератури, оригінальні дослідження, погляд на проблему

рини із мерказоліл-індукованим гіпотиреозом; 3 - тварини з хімічним опіком рогівки (термін спостереження 24 год, 7, 14 і 21 доба після травми); 4 - тварини з хімічним опіком рогівки на тлі попередньо змодельованого гіпотиреозу у ці ж терміни спостереження.

Продукцію активних форм кисню (АФК) у мононуклеарних лейкоцитах (МНЛ) визначали методом проточної цитометрії на апараті Еріх XL (Beckman Coulter, США) з використанням барвника дихлорфлуоресцеїну діацетату (Sigma Aldrich, США). Концентрацію дієнових кон'югатів (ДК) визначали за методом, описаним у роботі [5], ТБКактивних продуктів - за методикою, описаною у посібнику [8]. Вміст основ Шиффа визначали спектрофотометричним методом [9].

Визначення достовірності відмінностей порівнюваних параметрів між різними вибірками проводили з використанням t-критерію Стьюдента (за нормального розподілу результатів) чи Манна-Уітні (у випадку розподілу, що не був нормальним). Достовірними вважали відмінності при $\mathrm{p} \leq 0,05$. Для розрахунків використовували комп'ютерну програму Microsoft Excel XP i STATISTICA. Статистичну обробку проведено у відділі системних статистичних досліджень ДВНЗ «Тернопільський державний медичний університет імені І. Я. Горбачевського МОЗ України».

Результати й обговорення. Як показали наші дослідження (табл. 1), рівень активних форм кисню у тварин з гіпотиреозом становив 68 \% від показника інтактних тварин. Це, ймовірно, є наслідком зниження активності метаболічних процесів, в тому числі й тих, які супроводжуються продукцією активних форм кисню, за умов дефіциту гормонів щитоподібної залози. Запальний процес супроводжувався розвитком оксидативного стресу, що характеризується збільшенням інтенсивності продукування активних форм кисню. На 1-шу добу хімічного опіку рогівки у еутиреоїдних тварин продукція АФК значно зростала і становила 148 \% від рівня інтактних, а до 7-ї доби від моменту моделювання патологічного процесу цей показник ще більше зріс і склав 201 \% від норми. До 14-ї доби рівень АФК дещо знизився стосовно попереднього терміну спостереження і становив 187 \% від норми, а до 21-ї доби склав 113 \%, однак все ж достовірно відрізнявся від рівня здорових тварин і значно перевищував показник тварин 3 гіпотиреозом.

Таблиця 1. Концентрація продуктів вільнорадикального окиснення у крові тварин з хімічним опіком рогівки та на тлі мерказоліл-індукованого гіпотиреозу, $\mathrm{M \pm m}$

\begin{tabular}{|c|c|c|c|c|c|}
\hline \multicolumn{2}{|l|}{ Група тварин/показник } & $\begin{array}{l}\text { АФК, } \\
\text { ум. од }\end{array}$ & $\begin{array}{c}\text { ГПЛ, } \\
\text { ум. од/мл }\end{array}$ & $\begin{array}{c}\text { ТБК-активні } \\
\text { продукти, мкмоль/л }\end{array}$ & $\begin{array}{c}\text { ШО, } \\
\text { ум. од/мл }\end{array}$ \\
\hline \multicolumn{2}{|l|}{ Інтактні, $(n=10)$} & $0,365 \pm 0,015$ & $5,2 \pm 0,30$ & $4,76 \pm 0,23$ & $0,074 \pm 0,004$ \\
\hline \multicolumn{2}{|l|}{ Гіпотиреоз, $(n=10)$} & $\begin{array}{c}0,248 \pm 0,012 \\
p<0,001\end{array}$ & $\begin{array}{c}2,05 \pm 0,18 \\
p<0,001\end{array}$ & $\begin{array}{c}1,66 \pm 0,16 \\
p<0,001\end{array}$ & $\begin{array}{c}0,46 \pm 0,07 \\
p<0,001\end{array}$ \\
\hline \multirow{4}{*}{$\begin{array}{l}\text { Хімічний опік рогівки, } \\
(n=10)\end{array}$} & 24 год. & $\begin{array}{c}0,542 \pm 0,023 \\
p_{1}<0,001\end{array}$ & $\begin{array}{l}6,70 \pm 0,20 \\
\mathrm{p}_{1}<0,001\end{array}$ & $\begin{array}{l}5,57 \pm 0,16 \\
\mathrm{p}_{1}<0,001\end{array}$ & $\begin{array}{c}0,119 \pm 0,014 \\
p_{1}<0,001\end{array}$ \\
\hline & 7-а доба & $\begin{array}{c}0,734 \pm 0,018 \\
p_{1}<0,001 \\
\end{array}$ & $\begin{array}{l}7,85 \pm 0,28 \\
\mathrm{p}_{1}<0,001 \\
\end{array}$ & $\begin{array}{l}7,48 \pm 0,20 \\
\mathrm{p}_{1}<0,001\end{array}$ & $\begin{array}{c}0,141 \pm 0,007 \\
\mathrm{p}_{1}<0,001 \\
\end{array}$ \\
\hline & $\begin{array}{l}14-a \\
\text { доба }\end{array}$ & $\begin{array}{c}0,682 \pm 0,008 \\
p_{1}<0,001\end{array}$ & $\begin{array}{l}7,40 \pm 0,25 \\
\mathrm{p}_{1}<0,001\end{array}$ & $\begin{array}{l}6,98 \pm 0,25 \\
p_{1}<0,001\end{array}$ & $\begin{array}{c}0,097 \pm 0,003 \\
p_{1}<0,001\end{array}$ \\
\hline & $\begin{array}{l}21-a \\
\text { до6а }\end{array}$ & $\begin{array}{c}0,412 \pm 0,011 \\
p_{1}<0,001\end{array}$ & $\begin{array}{l}5,85 \pm 0,18 \\
\mathrm{p}_{1}<0,001\end{array}$ & $\begin{array}{l}5,54 \pm 0,16 \\
p_{1}<0,001\end{array}$ & $\begin{array}{c}0,085 \pm 0,006 \\
p_{1}<0,001\end{array}$ \\
\hline \multirow{4}{*}{$\begin{array}{l}\text { Хімічний опік рогівки + } \\
\text { гіпотиреоз, }(n=10)\end{array}$} & 24 год. & $\begin{array}{c}0,314 \pm 0,011 \\
P_{1}<0,001 \\
P_{2}<0,001 \\
\end{array}$ & $\begin{array}{c}5,75 \pm 0,23 \\
\mathrm{P}_{1}<0,001 \\
\mathrm{P}_{2}<0,001 \\
\end{array}$ & $\begin{array}{l}5,38 \pm 0,24 \\
\mathrm{P}_{1}<0,001 \\
\mathrm{P}_{2}<0,001 \\
\end{array}$ & $\begin{array}{c}0,079 \pm 0,004 \\
\mathrm{p}_{1}<0,001 \\
\mathrm{p}_{2}<0,001\end{array}$ \\
\hline & 7-а доба & $\begin{array}{c}0,521 \pm 0,014 \\
P_{1}<0,001 \\
P_{2}<0,001\end{array}$ & $\begin{array}{l}6,60 \pm 0,13 \\
P_{1}<0,001 \\
P_{2}<0,001\end{array}$ & $\begin{array}{l}6,14 \pm 0,21 \\
p_{1}<0,001 \\
p_{2}<0,001\end{array}$ & $\begin{array}{c}0,103 \pm 0,002 \\
p_{1}<0,001 \\
p_{2}<0,001\end{array}$ \\
\hline & $\begin{array}{l}14-а \\
\text { доба }\end{array}$ & $\begin{array}{c}0,626 \pm 0,017 \\
P_{1}<0,001 \\
P_{2}<0,001\end{array}$ & $\begin{array}{l}6,75 \pm 0,21 \\
P_{1}<0,001 \\
P_{2}<0,001\end{array}$ & $\begin{array}{l}7,11 \pm 0,34 \\
p_{1}<0,001 \\
P_{2}<0,001 \\
\end{array}$ & $\begin{array}{c}0,109 \pm 0,004 \\
p_{1}<0,001 \\
p_{2}<0,001\end{array}$ \\
\hline & $\begin{array}{l}21-а \\
\text { доба }\end{array}$ & $\begin{array}{c}0,672 \pm 0,012 \\
P_{1}<0,001 \\
P_{2}<0,001\end{array}$ & $\begin{array}{l}7,50 \pm 0,15 \\
\mathrm{P}_{1}<0,001 \\
\mathrm{P}_{2}<0,001\end{array}$ & $\begin{array}{c}6,95 \pm 0,268 \\
p_{1}<0,001 \\
p_{2}<0,001\end{array}$ & $\begin{array}{c}0,125 \pm 0,014 \\
p_{1}<0,001 \\
p_{2}<0,001\end{array}$ \\
\hline
\end{tabular}


Огляди літератури, оригінальні дослідження, погляд на проблему

Моделювання хімічного опіку рогівки кролям, яким протягом 60-ти діб вводили мерказоліл, супроводжувалось менш інтенсивним зростанням АФК, ніж у еутиреоїдних тварин, а на 1-шу добу показник був навіть меншим за рівень контролю і склав 86 \%. Впадає у вічі тенденція до поступового зростання АФК у подальші терміни спостереження і до 21-ї доби показник в 1,8 раза перевищував норму і був достовірно вищим від рівня еутиреоїдних тварин.

Аналогічна тенденція спостерігалась і стосовно початкових і проміжних продуктів ліпопероксидації. Зокрема, у тварин зі змодельованим гіпотиреозм концентрація гідропероксидів ліпідів була нижчою від рівня інтактних тварин на 61 \%. Вміст ГПЛ у сироватці крові тварин з хімічним опіком рогівки на 1-шу добу становив 129 \% від аналогічного показника інтактних тварин і зростав до 7-ї доби (151 \%), а у подальшому знижувався і склав 113 \% на 21-у добу спостереження. За умов моделювання хімічного опіку рогівки на тлі гіпотиреозу на початкових етапах формування патологічного процесу зростання концентрації ГПл було менш стрімким, ніж в еутиреоїдних тварин, однак у більш пізні терміни спостереження (на 14-у і 21-у доби) рівень початкових продуктів ліпопероксидації і надалі зростав, на відміну від еутиреоїдних тварин, у яких він поступово знижувався. Відповідно до 21-ї доби показник склав 144 \% від рівня інтактних тварин, тоді я к в еутиреоїдних кролів - $116 \%$.

Зниження продукції супероксидного аніонрадикала НАДФН-оксидазою нейтрофілів у кролів 3 гіпотиреозом супроводжувалось також зменшенням рівня кінцевого продукту ліпідної пероксидації-ТБК-активних продуктів у сироватці крові на всіх етапах експерименту. За умов експериментального хімічного опіку рогівки їх вміст у сироватці крові перевищував показник здорових кролів в 1,2 раза. До 7-ї доби концентрація ТБКактивних продуктів у сироватці крові суттєво зросла і становила 157 \% від рівня інтактних тварин, а у подальшому знижувалась, досягши до 21-ї доби рівня 112 \% від норми. Моделювання хімічного опіку рогівки на тлі гіпотиреозу не супроводжува- лось суттєвим зростанням ТБК-активних продуктів. На першу добу з моменту нанесення опікової травми рівень ТБК-активних продуктів у кролів 3 гіпотиреозом був дещо нижчим, порівняно із тваринами з нормальною функцією щитоподібної залози, однак до 14-ї доби показники вирівнялись, а на 21-у добу навпаки, рівень ТБК-активних продуктів тварин з гіпотиреозом в 1,6 раза перевищував показник еутиреоїдних тварин.

Зафіксовані нами зміни кінцевого продукту ліпопероксидації - шиффових основ - підтверджують попередню тенденцію. Уведення мерказолілу спричинилося до значного зниження вмісту основ Шиффа і їх концентрація складала 62 \% від рівня здорових тварин. У кролів з хімічним опіком рогівки показник на 1-шу добу становив 161 \% від рівня здорових тварин, на 7-му - $190 \%$, а до 21-ї знизився до $114 \%$, тоді як моделювання патологічного процесу на тлі гіпотиреозу призвело до значно менших змін на початкових етапах - відповідно 103 \% на 1-шу і 139 \% від норми на 7-му, однак на 14-у добу показник склав уже $147 \%$, а на 21-у 169 \% від рівня інтактних тварин, що в 1,3 раза вище, ніж в еутиреоїдних кролів.

Результати наших досліджень, а також дані інших авторів показали, що гіпотироїдні кролі стійкіші до оксидативного стресу та тканинного пошкодження, ніж еутиреоїдні тварини [16].

Дослідження процесів ліпопероксидації у волозі передньої камери ока дозволило нам підтвердити ті ж тенденції, які ми спостерігали у сироватці крові. Зокрема, в групі еутиреоїдних тварин інтенсивне зростання концентрації гідропероксидів ліпідів у початкові терміни спостереження (190\%), змінилось її наближенням до норми на 21-у добу (112 \%). Однак у тварин з порушенням функції щитоподібної залози навпаки, на початкових етапах показник був нижчим за норму (80\%), а до 21-ї доби суттєво зростав і склав 131 \% від рівня здорових тварин. Показники ТБК-реагуючих продуктів і основ Шиффа у групі тварин з гіпотиреозом хоч і не знижувались, як це мало місце з ГПЛ, однак їх зростання було значно меншим, ніж у групі еутиреоїдних тварин, а до завершення експерименту вони навпаки, зростали (табл. 2).

Таблиця 2. Концентрація продуктів ліпідної пероксидації у внутрішньоочній рідині передньої камери ока тварин з хімічним опіком рогівки на тлі мерказоліл-індукованого гіпотиреозу, $\mathrm{M \pm m}$

\begin{tabular}{|l|c|c|c|}
\hline \multicolumn{1}{|c|}{ Група тварин/показник } & $\begin{array}{c}\text { ГПл, } \\
\text { ум. од/мл }\end{array}$ & $\begin{array}{c}\text { ТБК-активні } \\
\text { продукти, мкмоль/л }\end{array}$ & $\begin{array}{c}\text { шО, } \\
\text { ум. од/мл }\end{array}$ \\
\hline 1 & 2 & 3 & 4 \\
\hline Інтактні, $(n=10)$ & $4,90 \pm 0,10$ & $5,13 \pm 0,20$ & $0,038 \pm 0,001$ \\
\hline Гіпотирео3, $(n=10)$ & $3,95 \pm 0,05 p<0,001$ & $3,28 \pm 0,08 p<0,001$ & $\begin{array}{c}0,027 \pm 0,002 \\
p<0,001\end{array}$ \\
\hline
\end{tabular}




\begin{tabular}{|c|c|c|c|c|}
\hline \multicolumn{2}{|l|}{1} & 2 & 3 & 4 \\
\hline \multirow{2}{*}{$\begin{array}{l}\text { Хімічний опік рогівки, } \\
(n=10)\end{array}$} & 7 -а доба & $\begin{array}{l}9,30 \pm 0,64 \\
p_{1}<0,001\end{array}$ & $\begin{array}{l}7,18 \pm 29 \\
\mathrm{p}_{1}<0,001\end{array}$ & $\begin{array}{c}0,092 \pm 0,002 \\
\mathrm{P}_{1}<0,001\end{array}$ \\
\hline & 21-а доба & $\begin{array}{l}5,50 \pm 0,45 \\
\mathrm{p}_{1}<0,001\end{array}$ & $6,03 \pm 0,28 p_{1}<0,001$ & $\begin{array}{c}0,079 \pm 0,004 \\
p_{1}<0,001\end{array}$ \\
\hline \multirow{2}{*}{$\begin{array}{l}\text { Хімічний опік рогівки + гіпотиреоз, } \\
\text { (n=10) }\end{array}$} & 7-а доба & $\begin{array}{c}3,90 \pm 0,31 \\
\mathrm{P}_{1}<0,001 \\
\mathrm{P}_{2}<0,001 \\
\end{array}$ & $\begin{array}{c}5,57 \pm 0,21 \mathrm{p}_{1}<0,001 \\
\mathrm{p}_{2}<0,001\end{array}$ & $\begin{array}{c}0,042 \pm 0,002 \\
\mathrm{p}_{1}<0,001 \\
\mathrm{p}_{2}<0,001\end{array}$ \\
\hline & 21-а доба & $\begin{array}{l}6,40 \pm 0,43 \\
P_{1}<0,001 \\
P_{2}<0,001\end{array}$ & $\begin{array}{c}5,34 \pm 0,12 \mathrm{p}_{1}<0,001 \\
\mathrm{p}_{2}<0,001\end{array}$ & $\begin{array}{c}0,081 \pm 0,002 \\
p_{1}<0,001 \\
P_{2}<0,001\end{array}$ \\
\hline
\end{tabular}

Висновки. Зниження метаболічних і оксидативних процесів в осередку ушкодження при гіпотиреозі супроводжується зниженням продукування активних форм кисню мононуклеар- ними лейкоцитами, зменшенням рівня гідропероксидів ліпідів, ТБК-активних продуктів і основ Шиффа як в осередку ушкодження рогівки, так i в крові.

\section{ЛITEPATУРA}

1. Герасимець А. Ю. Динаміка продуктів пероксидного окиснення ліпідів та антиоксидантного захисту в крові кроля за умов механічної непроникаючої травми рогівки / А. Ю. Герасимець // Вісник наукових досліджень - 2013. - № 2 (71). - С. 116-118.

2. Григорьев С. С. Клинико-лабораторные исследования в диагностике повреждений роговицы : автореф. дисс. На соискание ученой степени канд. мед. наук: 14.03.10 / С. С. Григорьев. - Саратов, 2010. - 25 с.

3. Доклінічне вивчення тиростатичних та тироїдстимулюючих засобів // Доклінічні дослідження лікарських засобів : метод. рекомендації. - Київ, 2001.- С. 409-420.

4. Науково-практичні рекомендації з утримання лабораторних тварин та роботи з ними / Ю. М. Кожем'якін, О. С. Хромов, М. А. Філоненко [та ін.]. - К. : Авіцена, 2002. $-156 \mathrm{C}$.

5. Колесова О. Е. Пероксидное окисление липидов и методы определения продуктов липопероксидации в биологических средах / О. Е. Колесова, А. А. Маркин, Т. Н. Федорова // Лаб. дело. - 1984. - № 9. - С. 540-546.

6. Красновид Т. А. Об основных причинах удаления глазного яблока / Т. А. Красновид, Н. П. Тичина, В. В. Яни, Т. В. Наровченко // Мат-ли ІІ Міжнародної наук. конференції офтальмологів Причорномор'я. - Одеса, 2004. - С. 146-147.

7. Логай И. М. Актуальные вопросы профилактики инвалидности больных и инвалидов с патологией глаз в Украине и научное обоснование механизмов повышения ее эффективности / И. М. Логай, Н. М. Сергиенко, Т. В. Крыжановская // Мат-ли наукової конференції офтальмологів, присвяченої 125-річчю 3 дня народження В. П. Філатова. - 2000. - С. 438-440.

8. Медицинские лабораторные технологии : руководство по клинической лабораторной диагностике : в 2 т. / [В. В. Алексеев и др.]; под ред. А. И. Карпищенко. - 3-е изд., перераб. и доп. - Т. 2 - М. : ГЭОТАР-Медиа, 2013. -792 c.

9. Хышиктуев Б. С. Методы определения продуктов перекисного окисления липидов в конденсате выдыхаемого воздуха и их клиническое значение / Б. С. Хышиктуев, Н. А. Хышиктуева, В. Н. Иванов // Клиническая лабораторная диагностика. - 1996. - № 3. С.13-15.

10. Anterior lamellar keratoplasty over penetrating keratoplasty for optical, therapeutic, and tectonic indications / M. Ang, J. S. Mehta, A. Arundhati [et al.] // Am J. Ophthalmol - 2009. - Vol. 147. - P. 697-702.

11. Destafeno J. J. Topical bevacizumab therapy for corneal neovascularization / J. J. DeStafeno, T. Kim // Arch. Ophthalmol. - 2007. - Vol. 125 (6). - P. 834-836.

12. Isman C. A. Methimazole-induced hypothyroidism in rats ameliorates oxidative injury in experimental colitis / C. A. Isman, B. C. Yegen, I. Alican // J. Endocrinol. - 2003. Vol. 177/- № 3 . P. 471-476.

13. Kuckelkorn R. Treatment of severe eye burns by Tenon-plasty / R. Kuckelkorn, N. Schrage, M. Reim // Lancet. - 1995. - Vol. 345 (8950). - P. 657-658.

14. Leonard R. Statistics on Vision Impairment: A Resource Manual / Leonard R. - New York : NY Lightouse International, 2000.

15. Analysis of corneal surface evolution after moderate alkaline burns by using impression cytology / LópezGarcía J. S., Rivas L., García-Lozano I., Murube J. // Cornea. - 2006. - № 25 (8). - P. 908-913.

16. Thyroid hormone regulation of cell migration and oxidative metabolism in polymorphonuclear leukocytes: clinical evidence in thyroidectomized subjects on thyroxine replacement therapy / Marino F., Guasti L., Cosentino M. [et al.] // Life Sci. - 2006. - Vol. 78, № 10. - P. 1071-1077. 
Огляди літератури, оригінальні дослідження, погляд на проблему

17. Smith D. The Epidemiology and Diagnosis of Penetrating Eye Injuries / Smith D., Keith W., Stack L. // Acad. Emerg. Med. - 2002. - V. 9, № 3. - P. 209-213.

18. Proteomics of the aqueous humor in healthy New Zealand rabbits / Stastna M., Behrens A., Noguera G. [et al.] // Proteomics. - 2007. -№ 7 (23). - P. 4358-4375.

19. Wagoner M. D. Chemical injuries of the eye: current concepts in pathophysiology and therapy / M. D. Wagoner // Survey of Ophthalmology. - 1997. - Vol. 41 (4). P. 275-313.

\section{INTENSITY OF LIPID INTENSITY OF PEROXIDATION IN RABBITS WITH CHEMICAL BURNS OF THE CORNEA AGAINST MERKAZOLIL-INDUCED HYPOTHYROIDISM}

\section{@Z. L. Savchuk}

\section{SHEI «Ternopil State Medical University named after I. Gorbachevskogo Ministry of Health of Ukraine»}

SUMMARY. The article analyzes the results of a study of lipid peroxidation intensity of blood and intraocular fluid of the anterior chamber of rabbit corneal chemical burns caused by the imposition of filter paper moistened with $1 \mathrm{~N} \mathrm{NaOH}$ against the backdrop previously simulated merkazolil-induced hypothyroidism. Found that in animals with chemical burns to the cornea background hypothyroidism compared with evtyroyidnymy animals detected a significant reduction of reactive oxygen species production by mononuclear white blood cells, inhibition of lipid peroxidation intensity, resulting in reducing the concentration of lipid hydroperoxides, TBA-reactive products and Schiff bases in blood and intraocular fluid of the anterior chamber of the eye. It is concluded that the conditions associated deficiency of thyroid hormones is a suppression of free radical processes as a place of destruction, and the body as a whole.

KEY WORDS: burn the cornea, hypothyroidism, lipid peroxidation 